Karmawibangga : Historical Studies Journal, Vol: 02, No: 02, 2020: 77-85

e-ISSN: 2715-4483

htpps://journal.upy.ac.id/index.php/karmawibangga

\title{
PERANAN HAJI MISBACH DALAM PERGERAKAN ISLAM KOMUNISME DI SURAKARTA PADA TAHUN 1914-1926
}

\author{
Beky Frisca Andriani \\ Program Studi Pendidikan Sejarah Universitas PGRI Yogyakarta \\ E-mail: friscabecky@gmail.com
}

\begin{abstract}
ABSTRAK
Penelitian ini bertujuan untuk: (1) mendeskripsikan biografi Haji Misbach; (2) mendeskripsikan pemikiran Haji Misbach mengenai gerakan komunisme Islam; (3) mendeskripsikan peran Haji Misbach dalam pergerakan komunisme Islam di Surakarta pada tahun 1914-1926.

Metode penelitian yang digunakan dalam penelitian ini adalah metode historis yang ditulis secara deskriptif-analitis. Dengan menggunakan pendekatan historis, politik, sosial dan religi. Tahap pertama yaitu heuristik. Kedua, verifikasi. Ketiga, interpretasi. Keempat, historiografi, dengan sifat penelitian studi literatur atau kepustakaan.

Hasil dari penelitian ini diketahui bahwa: (1) Haji Misbach terlahir dengan nama Ahmad, di Kauman, Surakarta, pada 1876. Ia besar di lingkungan keluarga pedagang batik. Ia lebih dikenal dengan nama Haji Misbach; (2) Haji Misbach ingin menyandingkan antara ajaran komunisme dan ajaran Islam. Dalam pemikirannya, Haji Misbach menyerukan kepada umat Islam untuk berjuang dan berjihad melawan kaum kapitalis dan kolonialisme Belanda. Di satu sisi, Komunisme merupakan sebuah alat perjuangan untuk melawan kapitalisme; (3) Peranan Haji Misbach dalam pergerakan komunisme Islam terjadi selama tahun 1914 sampai 1926. Ia banyak melakukan perjuangan dengan cara bergabung di beberapa organisasi serta aktif mendirikan, memimpin, dan mengelola sebuah surat kabar yang dijadikannya sebagai media untuk melakukan propaganda memperjuangkan
\end{abstract}

kebebasan masyarakat dari belenggu Kapitalisme yang berbungkus kolonialisme penjajah.

Kata Kunci: Haji Misbach, Islam, Komunisme

\section{ABSTRACT}

This study aims to: (1) describe the biography of Haji Misbach; (2) describe Haji Misbach's thoughts about the Islamic communism movement; (3) to describe the role of Haji Misbach in the Islamic communism movement in Surakarta in 19141926.

The research method used in this research is a historical method written descriptively-analytically. By using historical, political, social and religious approaches. The first stage is heuristics. Second, verification. Third, interpretation. Fourth, historiography, with the nature of research, literature or literature studies.

The results of this study indicate that: (1) Haji Misbach was born with the name Ahmad, in Kauman, Surakarta, in 1876. He grew up in a family of batik traders. He is better known as Haji Misbach; (2) Haji Misbach wanted to juxtapose the teachings of communism and Islam. In his thought, Haji Misbach called on Muslims to fight and jihad against the capitalists and Dutch colonialism. On the one hand, Communism is a means of struggle against capitalism; (3) The role of Haji Misbach in the Islamic communism movement occurred during 1914 to 1926. He fought a lot by joining in several organizations and was active in establishing, 
leading, and managing a newspaper which he used as a media to carry out propaganda fighting for people's freedom from shackles. Capitalism wrapped in colonialism.

Keywords: Haji Misbach, Islam, Communism

\section{PENDAHULUAN}

Awal abad 20 menjadi bagian penting dalam sejarah pergerakan yang terjadi di Surakarta. Surakarta merupakan kota trodisional Jawa yang memiliki makna penting dalam sejarah perkembangan gerakan Islam dan politik di Indonesia. Pada era kolonial, di Surakarta berkembang gerakan perlawanan yang dikenal dengan komunisme Islam yang dipelopori oleh Moehammad Misbach. Gerakan ini menekankan pada aksi propaganda anti kapitalisme melalui kotbah dan pernyataan bahwa komunisme dan Islam memiliki doktrin yang sama (Kuswono, Ketut, dan Ragil, 2019: 59).

Komunisme didasarkan pada ajaran filsafat Marx yang dikenal dengan Marxisme. Ajaran Marxisme menjadi nyata dan meluas setelah revolusi komunis di Rusia pada Oktober 1917 di bawah kepemimpinan Lenin. Sehingga kemudian ajaran resmi komunisme didasarkan pada dua tokoh ini yang dikenal sebagai ajaran ML - Marxisme Leninisme. Marxisme pada pendiriannya menolak kapitalisme, menolak akan kelaskelas masyarakat, menolak eksploitasi negara, spesialisasi, penumpukan kekayaan, etika pencarian diri dan terutama menolak perbudakan manusia, yakni perusakan sifat esensial manusia dalam system produksi dan tatanan sosial (Nor Hiqmah, 2000:61).

Gerakan komunisme Islam di Surakarta tumbuh dan berkembang karena mengikuti dinamika sosial-politik yang melingkupinya. Komunisme dijadikan sebagai wadah perjuangan bagi para kaum Islam revolusioner dan kaum proletar yang berada di Surakarta. Pada penelitian kali ini peneliti memfokuskan penelitian pada sosok Haji Misbach sebagai tokoh pergerakan komunisme Islam di Surakarta. Haji Misbah adalah seorang mubaliqh yang berpendidikan pesantren. Aktor utama pergerakan komunisme Islam di Surakarta adalah Hadji Moehammad Misbach, yang selanjutnya dikenal dengan Haji Misbach. Haji Misbach lahir pada tahun 1876 di Kauman, Surakarta dengan nama Achmad. Ia menjadi simbol penting bagi sejarah zaman pergerakan di Surakarta, karena ia memiliki watak pemberani, alim, revolusioner, komitmen terhadap Islam, serta radikal dalam melakukan trobosan baru untuk sebuah perubahan (Syamsul Bakri, 2015: 99).

Peneliti membatasi dari tahun 1914 sampai dengan tahun 1926. Tahun 1914 dipilih karena tahun tersebut merupakan tahun hijrahnya lokomotif komunisme islam dari dunia usaha ke kancah sosial politik, jurnalisme, dan dakwah. Alasan lain dipilihnya tahun 1914 adalah karena pada tahun tersebut juga menjadi tahun penting dalam pergerakan di Hindia Belanda yang ditandai dengan berdirinya IJB (Inlandsche Journalisten Bond) atau Ikatan Wartawan Bumiputra, yang didirikan oleh Mas Marco Kartodikromo, serta mulai masuk dan aktifnya Haji Misbach menjadi anggota IJB dan organisasi-organisasi lainnya. Penelitian ini diakhiri pada tahun 1926 yang seiring berakhirnya masa perjuangan Haji Misbach setelah tutup usia dikarenakan penyakit malaria yang dideritanya. Dilatarbelakangi dari hal tersebut kemudian disusunlah penelitian dengan judul "Peranan Haji Misbach Dalam Pergerakan Komunisme Islam Di Surakarta Pada Tahun 1914-1926" (Syamsul Bakri, 2015: 5).

\section{METODE PENELITIAN}

Metode yang digunakan dalam penelitian ini adalah metode historis atau sejarah. Pemilihan metode ini karena objek yang dikaji adalah peristiwa masa lalu. 
Kuntowijoyo (2003: 19) mengartikan metode sebagai ilmu yang membicarakan jalan, sehingga metode sejarah merupakan petunjuk pelaksanaan dan petunjuk teknis tentang bahan, kritik, interpretasi, dan penyajian sejarah. Metode sejarah terdiri atas empat kelompok kegiatan atau empat langkah penelitian, yaitu: (1) heuristik (pengumpulan data), (2) kritik (penilaian data), (3) interpretasi (penafsiran data), dan (4) historiografi (penyimpulan dan penulisan) (W. Surakhmad, 1982: 133).

Adapun langkah-langkah penelitian ini akan dijelaskan sebagai berikut: pertama, Heuristik, yaitu mengumpulkan data-data dari berbagai sumber yang terkait dengan topik penelitian. Adapun sumber-sumber tersebut ditemukan dan dikumpulkan dari perpustakaan Bantul, perustakaan Kota Yogyakarta, perpustakaan UGM, dan toko buku online. Adapun sumber sekunder yang digunakan dalam penelitian ini, yaitu buku, artikel, jurnal dan skripsi yang terkait dengan tema penelitian yang ditulis oleh peneliti sebelumnya.

Kemudian tahap kedua adalah Kritik Sumber/Verivikasi, Kritik adalah suatu kegiatan menyelidiki keautentikan dari keaslian data dalam hal ini data yang telah diperoleh diklarifikasikan mana yang autentik dan mana yang tidak autentik yang tidak dapat digunakan untuk mendukung penelitian. Data yang tidak autentik tidak dipakai dan data yang dipakai adalah data yang autentik yang dapat mendukung penelitian. Selanjutnya data yang terkumpul dikritik dengan menggunakan dua cara: (1) kritik ekstren, digunakan untuk menguji keaslian (otentitas) sumber; (2) kritik intern, digunakan untuk menguji kesahihan (kreadibilitas) sumber (Dudung A, 1999: 5859), sehingga didapatkan fakta sejarah mengenai peranan Haji Misbach dalam pergerakan komunisme Islam di Surakarta pada tahun 1914-1926.
Pada tahap ketiga adalah Interpretasi, Interpretasi sejarah disebut juga dengan analisis. Dalam hal ini pada langkah intepretasi ada dua metode yang digunakan, yaitu analisis dan sintesis. Keduanya dipandang sebagai metode utama di dalam interpretasi (Kuntowijoyo, 2003: 100). Pada tahap ini penulis berusaha mencari faktafakta terkait dengan Haji Misbach, karena penulis tidak mengetahui secara langsung sosok Haji Misbach dalam perjuangannya menyandingkan antara ajaran komunisme dan ajaran Islam. Maka fakta-fakta yang telah ada dijadikan sebagai landasan untuk merekontruksi peristiwa tersebut.

Kemudian tahap ke empat adalah Historiografi, Historiografi adalah suatu kegiatan untuk menyampaikan sintesis yang diperoleh dalam bentuk suatu cerita. Langkah terakhir ini merupakan langkah menulis sumber-sumber sejarah yang telah dikumpulkan, dianalisa, dan ditafsirkan sehingga tersusun hasil penelitian tentang Peranan Haji Misbach Dalam Pergerakan Komunisme Islam di Surakarta Pada Tahun 1914-1926. Dan penyajian dalam bentuk tulisan mempunyai tiga bagian: (1) Pengantar, (2) Hasil Penelitian, dan (3) Simpulan (Kuntowijoyo, 2003: 80-81).

\section{HASIL DAN PEMBAHASAN}

\section{Biografi Haji Misbach}

Pada tahun 1876 di Kauman, Surakart, Haji Moehammad Misbach yang dikenal sebagai seorang mubalig. Haji Misbach merupakan anak kedua dari Dipowirono, pengusaha batik yang religius dan ternama. Nama Haji Misbach sempat beberapa kali berubah-ubah, ketika masih kecil namanya "Achmad Darmodiprono". Setelah menikah namanya berganti menjadi "Darmodiprono", ketika sudah dewasa dan mampu mencari nafkah untuk menghidupan keluarganya, namanya berubah menjadi Haji Mohammad 
Misbach, yang diubahnya setelah menjalankan ibadah haji di Mekah. Kehidupan Haji Misbach semasa kecilnya berada di dalam lingkungan santri dan bersekolah di Sekolah Batangan Solo yang menjadi latar belakang pendidikannya. Selain dikenal sebagai mubalig yang saleh karena semasa dirinya kecil menghabiskan pendidikannya di pesantren, Haji Misbach juga pernah mengenyam pendidikan di sekolah khusus untuk masyarakat bumiputra di sekolah Ongko Loro selama delapan bulan lamanya (Shiraishi, 1997: 173).

Kediaman Haji Misbach sewaktu kecil berada persis di depan rumah tahanan Surakarta. Di dalam rumah yang berada di depan rumah tahanan Kota Surakarta tersebut tinggallah tiga orang wanita tua yang sudah janda, yaitu Dipowirono, Potroloemakso, dan Karjomarto. Mbok Dipowirono adalah ibu kandung dari Haji Misbach. Di dalam rumah tersebut selain tinggal bersama ibunya Haji Misbach juga tinggal bersama dengan saudara kandungnya yang bernama B.Soemebar. Pendidikan yang didapat dari pesantren yang berbasis agama membuat Haji Misbach memiliki kemampuan berbahasa Arab serta pemikiran dan kebiasaan Haji Misbach cenderung mengarah dalam hal agama daripada pendidikan modern. Seperti kebiasaan masyarakat Solo pada umumnya, saat beranjak dewasa Haji Misbach menjalani usaha sebagai seorang pedagang batik di daerah Kauman, Surakarta. Usaha batik yang dikelolanya dapat berkembang dengan baik sehingga ia mampu membuka rumah produksi batik. Namun akhirnya Haji Misbach tidak melanjutka usahanya berdagang batik, ia lebih meilih melanjutkan karirnya sebagai seorang tokoh yang anti pemerintah Hindia-
Belanda terhadap kapitalisme. Kontruksi pemikiran Misbach atas Islam dan komunisme sebagai betuk perlawanan terhadap kapitalisme yang dijalankan oleh Pemerintah Hindia-Belanda (Yolla Marta, 2017: 75).

\section{Pemikiran Haji Misbach Terhadap Gerakan Komunisme Islam}

Haji Misbach selain dikenal sebagai seorang mubalig ia juga merupakan salah satu orang yang dikenal dengan sebutan sang propagandis. Pemikirannya untuk menyandingkan Ajaran Islam dan Komunisme membuat ia dijuluki "Sang Haji Merah" (Rosyid, M., 2018). Hasil dari pemikiran Haji Misbach mengenai Komunisme Islam membawa pengaruh besar terhadap penghapusan kapitalisme yang lebih identik dengan penindasan dan kesengsaraan terhadap rakyat (Kuswono, dkk, 2019: 62).

Misbach ingin menyandingkan antara ajaran komunisme dan ajaran Islam. Ia terinspirasi dari ilmu keagamaan yang telah didapatnya sekaligus bacaan-bacaan dari karangan Marx, mengenai sistem komunisme sebagai bentuk perlawanan dari kaum buruh terhadap sistem kapitalisme yang selalu menjadi sebab adanya penindasan, pemerasan, dan lainlain. Komunisme dalam karangan Marx tersebut merupakan upaya buruh dalam memperjuangkan status sosialnya, yang tujuannya untuk menghapuskan sistem hak milik perorangan atas alat produksi menjadi alat produksi milik masyarakat. Hal ini menandakan bahwa komunisme merupakan suatu bentuk perlawanan terhadap kapitalisme untuk memperjuangkan hak-hak rakyat. Di sisi lain, Haji Misbach memandang bahwa agama Islam merupakan agama keselamatan. Ajaran Islam bersifat terbuka, tidak memaksa, dan tidak membedakan (Nor Hiqmah, 2000: 26) 
Dalam salah satu tulisannya yang berjudul "Islam dan Atoerannja", Haji Misbach mengutip dalam Al-Qur'an Jus 11 Ayat 84 menjelaskan bahwa Islam harus berlandaskan fikiran sehingga kita dapat menyebarkan keselamatan. Oleh sebab itu, menurut Haji Misbach komunisme dan Islam memiliki suatu keterkaitan atau hubungan. Ajaran Islam dan komunisme memiliki kesamaan yaitu sama-sama menjunjung tinggi hak serta menentang adanya penindasan dan kekerasan. Atas dasar itulah, Haji Misbach mencoba menyandingkan antara ajaran Islam dengan komunisme lewat tulisan yang dapat mempengaruhi kaum krama (buruh) untuk memperjuangkan hak-hak mereka (Nor Hiqmah, 2000: 27).

Berdasarkan pemikiran Haji Misbach tersebut menyebabkan adanya gerakan anti kapitalisme yakni gerakan yang menentang adanya kapitalis (Yusdani, Y., 2002). Pengaruh yang ditimbulkan akibat dari gerakan komunisme Islam di Surakarta bagi dunia pergerakan Hindia Belanda adalah semangatnya menentang kapitalisme dan kolonialisme. Gerakan yang dilakukan oleh kelompok komunis putihan telah memberikan keberanian bagi kaum bumi putera untuk melawan penindasan (Syamsul Bakri, 2015:313). Anti kapitalisme memberikan pengaruhi pada pemikiran Misbach terkait dengan penyatuan antara ajaran Islam dengan komunisme atau yang lebih dikenal dengan komunisme Islam. Komunisme Islam disebarluaskan melalui berbagai media massa serta melalui tulisan-tulisan Haji Misbach yang telah membangkitkan semangat perjuangan rakyat bumiputera untuk melawan penindasan dan kolonialisme yang dilakukan oleh kaum kapitalis (Supriyadi, A., 2014: 41).

Misbach juga menunjukkan kepada publik dengan tulisan, perkataan, dan perbuatan secara nyata tetang pentingnya memberikan advokasi kepada masyarakat tertindas. Pengaruh dari pemikiran misbach yang disalurkan melalui berbagai tulisan, perkataan, dan perbuatannya secara nyata telah mengajarkan kepada berbagai pihak untuk membantu dan memperdulikan kaum tertindas. Kesamaan hak agar dapat memperoleh keadilan harus ditegakkan. Misbach telah memberikan berbagai petunjuk-petunjuk ataupun pencerahan kepada berbagai pihak tentang pentingnya memberikan dukungan atau advokasi bagi masyarakat yang tertindas. Secara lebih luas, pemikiran Haji Misbach tentang komunisme dan Islam yang menjadi Komunisme Islam telah banyak mengilhami dan inspirasi dari banyak kaum pergerakan yang ikut memperdulikan ketertindasan masyarakat. Soewarsono dkk (2013:54) menyatakan bahwa Haji Misbach berupaya keras untuk mendekatkan pesan Islam setara dengan pesan yang diajarkan dalam komunisme. Dalam ruang sosial yang lebih luas, posisi Haji Misbach sangat unik. Ia berbeda dengan kebanyakan pengikut kelompok Islam garis 'kanan' (fundamentalis) yang menuduh bahwa komunisme itu ateis dan melakukan sikap radikalisme dengan jalan pertumpahan darah. Selain itu, pengaruh pemikiran Haji Misbach terhadap rakyat bumi putera juga berpengaruh terhadap kemandirian bagi rakyat bumiputera itu sendiri (Kuswono, Ketut, dan Ragil, 2019: 65).

Bagi Misbach, Islam dan komunisme adalah solusi yang paling tepat. Islam merupakan pondasi dasar dan pedoman hhidup bagi manusia. Islam tidak hanya mengatur hubungan Tuhan dengan Makhluknya, akan tetapi Islam mengatur segala aspek kehidupan. Islam juga mengajarkan untuk tidak melakukan kedzaliman dan mengajarkan tentang 
keadilan. Komunisme dari segi positif merupakan suatu bentuk ajaran untuk persamaan hak. Seperti yang diungkapkan Karl Marx bahwa kejahatan sosial adalah kepemilikan hak pribadi yang mengakibatkan kerugian pada rakyat. Islam dan komunisme, keduanya bersifat kerakyatan, langsung membidik sasaran untuk kepentingan bersama (Hiqmah, N. 2006). Misbach mempunyai pandangan bahwa Islam mengajarkan untuk tidak saling menindas, oleh sebab itu atas dasar Islam, Misbach berkeinginan untuk melawan kolonialisme dengan menyatukan ajaran Islam dengan komunisme. Hal ini menjadi pertentangan bagi organisasi Islam yaitu SI dan Muhammadiyah. Kedua organisasi tersebut menganggap bahwa Misbach memilih untuk menjadi kaum komunis daripada memperjuangkan kemurnian Islam. Padahal disisi lain, Misbach menginginkan agar komunisme dan Islam berjalan berdampingan melawan kolonialis (Shiraishi, 1997: 343).

\section{Peranan Haji Misbach Dalam Pergerakan Komunisme Islam Di Surakarta Pada Tahun 1914-1926}

Pergerakan komunisme Islam yang dilakukan oleh Haji Misbach dimulai pada tahun 1914 Haji Misbach mulai masuk menjadi anggota IJB (Inlandsche Journalisten Bond) yang didirikan oleh Marco Kartodikromo. Dari pengalaman yang didapat selama masuk menjadi anggota IJB kemudian pada tahun 1915 Haji Misbach menerbitkan surat kabar bulanan yang diberi nama Medan Moeslimin. Selain sebagai pendiri Medan Moeslimin tahun 1916 Haji Misbach juga ditunjuk menjadi ketua redaksi Medan Moesllimin bersama Hisamzaijinie sebagai redaktur. Lalu pada tahun 1917 Haji Misbach mendirikan surat kabar
Islam Bergerak. Pada tahun 1918 Haji Misbach dan Haroenrasjid membentuk perkumpulan mubalig revormasi yang diberi nama STAV (Sidiq, Tabligh, Amanah, dan Vathonah). Pada tanggal 13 April 1919 di Markas Sociteit Mangkunegara Surakarta, Haji Misbach memimpin kongres al-Islam yang diselenggarakan oleh perhimpunan STAV. STAV dan Haji Misbach menjadi perhimpunan dan sosok yang popular pada masanya. Haji Misbach juga aktif di beberapa organisasi selain STAV yaitu di Insulinde. Haji Misbach juga berperan sebagai wakil ketua Perkoempolan Kaoem Boeroeh dan Tani (PKBT) di Surakarta yang diketuai oleh Santoso. PKBT merupakan kelompok revolusioner. Di Surabaya pada tanggal 15 Februari 1919 pimpinan CSI (Centraal Sarekat Islam), Marco dan Semaoen mengususlkan untuk pengaktifan kembali SI Surakarta. Dari pertemuan tersebut menghasilkan pengaktifan Kembali SI Surakarta dengan Marko sebagai ketua, Misbach sebagai wakil ketua, dan R. Hadiasmara sebagai sekertaris. Sebulan kemudian tanggal 6 April 1919 pada saat yang sama dengan diadakannya vergadering, PKBT dan Insulinde yang mana Haji Misbach aktif di dalamnya, lalu pada tanggal 7 Mei 1919 Haji Misbach ditangkap oleh pihak kepolisian dengan tuduhan sebagai provokator dan penyebar benih kebencian terhadap pemerintah (Syamsul Bakri, 2015: 107).

Memasuki awal tahun 1920, Haji Misbach memutuskan untuk mengundurkan diri dari jabatannya sebagai ketua SATV dikarenakan ingin lebih aktif sebagai propagandis SI dan Insulinde. Pada tanggal 13 Mei 1920 Haji Misbach mulai menjadi propagandis SI di Kebumen. 14 Mei 1920 Haji Misbach menjadi orator dalam vergadering SI 
yang diadakan di Alijan (Kebumen) rumah Abdoelgani desa Soeratroenan. 15 Mei 1920 Haji Misbach juga menjadi propagandis vergadering grup SI Desa Ampih Kebumen. Pada tanggal $16 \mathrm{Mei}$ 1920 Haji Misbach di tangkap kembali atas tuduhan sebagai provokator pemogokan. 8-11 September 1920 Haji Misbach melakukan pemeriksaan di Landraad Klaten. Pemeriksaan kedua tanggal 11 September 1920, Haji Misbach didakwa melakukan pelanggaran hukum. Haji Misbach menjalani hukuman penjara selama dua tahun tiga bulan yang kemudian dibebaskan pada tanggal 21 Agustus 1922. Kemudian Haji Misbach Kembali pulang ke Surakarta. Ia kemudian mulai aktif lagi sebagai redaktur Islam Bergerak mulai edisi 1 November 1922, dan Medan Moeslimin edisi 10 November 1922 (Syamsul Bakri, 2015: 115).

Awal tahun 1923 Haji Misbach berpisah dengan sekutu lamanya, yaitu Fachrodin (Muhammadiyah) dan Dachlan, yang kemudian muncul sebagai propagandis PKI dan SI Merah. Pada bulam Maret 1923 Haji Misbach secara resmi bergabung dengan PKI dan SI Merah yang disampaikan pada saat kongres PKI dan SI Merah. Lalu pada bulan Oktober 1923 Haji Misbach mendirikan SR (Sarekat Ra'jat) Surakarta. Pada tanggal 20 Oktober 1923 Haji Misbach ditangkap bersama Moetakalimoen di landraad Semarang yang kemudian Haji Misbach dijatuhi hukuman pembuangan ke Manokwari dengan pasal 47 (pembuangan). Pembuangan Haji Misbach ini tidak lebih dikarenakan bentuk dari kediktatoran penguasa colonial. Pada tanggal 7 Agustus 1924 Haji Misbach beserta keluarga sampai di Manokwari. Pergerakan Haji Misbach dimulai dengan mendirikan SR Manokwari yang beranggotakan tidak lebih dari 20 orang yang meskipun tetap dibayang-bayangi oleh gerakan anggota kepolisian. Di antara tahun 1924-1925 selama berada dipembuangan Haji Misbach tetap aktif menulis artikel di Medan Moeslimin, yang khususnya membahas tentang hubungan antara komunisme dengan Islam (Syamsul Bakri, 2015: 126).

Pada tahun 1925 Haji Misbach meminta pada pemerintah untuk pergi ke negeri Belanda karena alasan Kesehatan, yang pada saat itu di Manokwari sedang terjadi wabah penyakit TBC yang mengakibatkan ia beserta keluarga juga terserang TBC. Namun pada 10 Juli 1925 istri Haji Misbach meninggal dunia. Lalu pada bulan September 1925 Haji Misbach diizinkan untuk ke luar negeri dengan biaya sendiri. Haji Misbach mengurungkan niatnya untuk pergi ke luar negeri, Haji Misbach lebih memilih untuk melanjutkan pergerakannya di Manokwari. Karena terserang menyakit TBC akhirnya Haji Misbach meninggal dunia pada 24 Mei 1926 (Syamsul Bakri, 2015: 127).

\section{KESIMPULAN DAN SARAN}

Haji Misbach lahir pada tahun 1876 di Kauman, Surakarta. Haji Misbach ingin menyandingkan antara ajaran komunis dan ajaran Islam. Dalam pemikirannya, Haji Misbach menyerukan kepada umat Islam untuk berjuang dan berjihad melawan kaum kapitalis dan kolonialisme Belanda. Di satu sisi, Komunisme merupakan sebuah alat perjuangan untuk melawan kapitalisme. Selama rentang waktu dari tahun 1914 sampai 1926 periode perjalanan Haji Misbach sebagai aktivis gerakan, tercatat bahwa Haji Misbach pernah bergabung dalam beberapa organisasi yang ada pada 
saat itu. Peran Haji Misbach dalam pergerakan komunisme Islam dimulai pada tahun 1914 dengan menjadi anggota IJB. Namun pada 24 Mei 1926 masa perjuangannya Haji Misbach berakhir akibat terserang penyakit malaria. Dari pembahasan "Peranan Haji Misbach Dalam Pergerakan Komunisme Islam Di Surakarta", dapat diambil pelajaran dan manfaat bagi pendidikan bahwa pentingnya semangat berjuang, mampu menyuarakan pemikirannya, serta rela berkorban sebagaimana yang terdapat pada diri Haji Misbach dapat dijadikan sebagai contoh untuk semangat pantang menyerah.

Setelah melakukan penelitian tentang "Peranan Haji Misbach Dalam Pergerakan Komnunisme Islam Di Surakarta Pada Tahun 1914-1926", maka dapat diajukan saransaran kepada: (1) Bagi dunia Pendidikan, untuk lebih memperluas pengetahuan siswa tentang sejarah lokal di Indonesia pada abad 20 yang berada di daerah Surakarta, (2) Bagi para guru Sejarah, diharapkan dapat menambah pengetahuan kesejarahan menegenai gerakan Islam dan komunisme yang ada di Surakarta pada abad 20, (3) Bagi mahasiswa prodi pendidikan sejarah dapat dijadikan sebagai referensi bagi mahasiswa untuk menambah pemahaman tentang sejarah sosial di Kota Surakarta dan Sejarah Indonesia Madya, terutama mengenai gerakan radikal Islam yang ada pada abad ke 20 .

\section{DAFTAR RUJUKAN}

Abdulrahman, Dudung. 1999. Metode Penelitian Sejarah. Jakarta: Logos Wacana Ilmu.

Bakri, Syamsul. 2015. Gerakan Komunisme Islam Surakarta 1914-1942. Yogyakarta: LkiS Pelangi Aksara.
Hiqmah, Nor. 2011. Pertarungan Islam dan Komunisme Melawan Kapitalisme: Teologi Pembebasan Kyai Kiri Haji Misbach. Malang: Madani, Edisi revisi cetakan pertama.

, $\overline{\text { dan }} \begin{aligned} & \text { 2000. H. M. Misbach: Sosok } \\ & \text { Kontroversi Pemikirannya. }\end{aligned}$ Yogyakarta: Yayasan Literasi Indonesia.

Kuntowijoyo. 2003. Metodologi Sejarah. Yogyakarta: PT. Tiara Wacana Yogya.

Kusuma, Yolla Marta. 2017, Warisan Pemikiran Haji Misbach Untuk Indonesia (Studi Eksploratif Pemikiran dan Pergerakan Haji Moehammad Misbach dalam Pers Indonesia Masa Kolonialisme Hindia-Belanda 1916-1926). Tesis. Malang: Fakultas Ilmu Sosial Dan Ilmu Politik Universitas Brawijaya

Kuswono, Ketut Adi Saputra, dan Ragil Agustono. 2019. "Menyandingkan Ajaran Islam dan Komunisme: Pemikiran Haji Misbach (19121926)". Jurnal Pendidikan Sejarah, Vol. 8, No. 2, 2019.

Misbach, Mohammad. Cet.1, 2016. Haji Misbach Sang Propagandis Aksi Propaganda di Surat Kabar Medan Moeslimin dan Islam Bergerak 1915-1926, Temanggung: Kendi Puri Indah.

Muhamad Hasyim, Arif. 2017. Komunisme Dalam Konteks Keislaman: Studi atas Pemikiran Haji Mohammad Misbach Pada Masa Kolonialisme Belanda Tahun 1876-1926. Penelitian. Yogyakarta: Fakultas Ushuluddin dan Pemikiran Islam UIN Sunan Kalijaka Yogyakarta. 
Rosyid, M. 2018. Dinamika haji Indonesia sejak era kolonial dan problematika calon haji ilegal. Ijtihad : Jurnal Wacana Hukum Islam dan Kemanusiaan, 17(2), 241. doi:10.18326/ijtihad.v17i2.241-259

Shiraishi, Takashi. 1997. Zaman Bergerak: Radikalisme Rakyat di Jawa 19121926. terj. Hilmar Farid, Jakarta: Pustaka Utama Grafiti.

Soewarsono. 2013. Berbareng Bergerak: Sepenggal Riwayat dan Pemikiran Semaon. Lkis: Yogyakarta.

Supariadi. 2014. Dinamika Kehidupan Relijius Kasunan Surakarta. Jakarta: Puslitbang Lektur dan Khazanah keagamaan Badan Litbang dan Diklat Kementerian Agama RI.

Surakhmad, Winarno. 1982. Pengantar Interaksi Belajar Mengajar, Dasar, dan Teknik Metodologi Pengajaran. Bandung: Tarsito. 